\title{
ANALISA KESEIMBANGAN INTERAKSI POPULASI TERUMBU KARANG, SIPUT DRUPELLA DAN PREDATORNYA MELALUI PHASE PORTRAIT
}

\author{
E. Asran'1, R. Ratianingsih², dan A. I. Jaya ${ }^{3}$ \\ 1,2,3 Program Studi Matematika Jurusan Matematika FMIPA Universitas Tadulako \\ Jalan Soekarno-Hatta Km. 09 Tondo, Palu 94118, Indonesia. \\ 1Erniasran@ymail.com, 2,3ratianingsih@yahoo.com
}

\begin{abstract}
The reduction problem of the quantity, quality and aesthetics of coral reefs in Indonesia need to overcome. The existence of coral reefs closely related with the slug Drupella as predators to coral reefs, while the existence of Drupella closely related to with the snail's predators that eat it. This research study mathematically, the interaction of coral reefs, Drupella and predatory snail's predators contained in an ecosystem. The goal is to get the ecosystem balance of the is models. The model is built by system of non linear autonomous differential equations that analysis around critical point and using Jacobi matrix. The system has three critical points $T_{1}=$ $(0,0,0), T_{2}=\left(0, \frac{-\psi_{3}+\mu_{33}}{\beta}, \frac{\psi_{2}-\mu_{22}}{\beta}\right)$ dan $T_{3}=\left(\frac{-\psi_{2}+\mu_{22}}{\alpha}, \frac{\psi_{1}-\mu_{11}}{\alpha}, 0\right)$. Analysis of the system around the critical point is done through the corresponding eigenvalues. The results showed that the critical point $T_{1}$ be stable if eligible the stability is $\psi_{1}<\mu_{11}, \psi_{2}<\mu_{22}$ dan $\psi_{3}<\mu_{33}$, with $\psi_{1}, \psi_{2}$ and $\psi_{3}$ respectively are the growth of coral reefs, snails Drupella and predators of snails Drupella while $\mu_{11}, \mu_{22}$ and $\mu_{33}$ is the death rate of the population respectively. Phase portrait at the critical point $T_{2}$ shows that the system is stable with spiral type while at the critical point $T_{3}$ indicates that the system is unstable. The system can be transformed into a stable critical points and two unstable critical points. The transform is due to changes in parameter known as bifurcation. This is a pitchfork bifurcation type. The Interaction of the population that considers the existence of corals at a critical point of unstable $T_{3}$ will move towards equilibrium point $T_{2}$. This indicates the need for special efforts to keep the existence of corals.
\end{abstract}

Keywords : Jacobi Matrix, Phase Portrait, Pitchfork Bifurcation, Stability, System Linearization

\section{ABSTRAK}

Masalah penurunan kuantitas, kualitas maupun estetika ekosistem terumbu karang di Indonesia perlu diatasi. Eksistensi terumbu karang berkaitan erat dengan siput Drupella sebagai pemangsa terumbu karang, sedangkan eksistensi siput Drupella berkaitan dengan predator yang memangsanya. Penelitian ini mengkaji secara matematis, interaksi dari terumbu karang, siput Drupella dan predator pemangsanya yang terdapat dalam suatu ekosistem. Tujuannya adalah untuk mendapatkan keseimbangan ekosistem dari suatu model yang merepresentasikannya. Model dibangun oleh suatu sistem persamaan diferensial autonomous non-linear yang kestabilannya dianalisa di sekitar titik kritisnya dengan menggunakan matriks Jacobi. Sistem memiliki tiga titik 
kritis $T_{1}=(0,0,0), T_{2}=\left(0, \frac{-\psi_{3}+\mu_{33}}{\beta}, \frac{\psi_{2}-\mu_{22}}{\beta}\right)$ dan $T_{3}=\left(\frac{-\psi_{2}+\mu_{22}}{\alpha}, \frac{\psi_{1}-\mu_{11}}{\alpha}, 0\right)$. Analisa terhadap sistem di sekitar titik kritis dilakukan melalui nilai eigen yang bersesuaian. Hasil penelitian menunjukan bahwa titik kritis $T_{1}$ akan stabil jika memenuhi syarat kestabilan yaitu $\psi_{1}<\mu_{11}, \psi_{2}<\mu_{22}$ dan $\psi_{3}<\mu_{33}$, dengan $\psi_{1}, \psi_{2}$ dan $\psi_{3}$ secara berturutturut adalah tingkat pertumbuhan terumbu karang, siput Drupella dan predator siput Drupella sedangkan $\mu_{11}, \mu_{22}$ dan $\mu_{33}$ adalah tingkat kematian masing-masing populasi tersebut. Phase portrait pada titik kritis $T_{2}$ menunjukan bahwa sistem stabil dengan tipe spiral, sedangkan pada titik kritis $T_{3}$ menunjukan bahwa sistem tidak stabil. Sistem ini dapat berubah menjadi satu titik kritis stabil dan dua titik kritis tidak stabil. Perubahan tersebut disebabkan karena perubahan parameter yang disebut sebagai bifurkasi. Jenis bifurkasi ini adalah pitchfork. Interaksi populasi yang mempertimbangkan eksistensi populasi terumbu karang pada titik kritis $T_{3}$ yang tidak stabil akan bergerak menuju titik kesetimbangan $T_{2}$. Hal ini menunjukkan perlunya upaya khusus untuk menjaga eksistensi populasi terumbu karang.

Kata Kunci : Bifurkasi Pitchfork, Kestabilan, Linearisasi Sistem, Matriks Jacobi, , Phase Portrait

\section{PENDAHULUAN}

\subsection{Latar Belakang}

Indonesia memegang peranan penting dibidang kelautan dunia, karena negeri ini memiliki laut yang luas dan di dalamnya memiliki keragaman hayati laut tertinggi di dunia, antara lain terdapat $60.000 \mathrm{~km}^{2}$ areal terumbu karang yang mencakup 15 persen terumbu karang dunia (Guntur, Prasetyo, \& wawan, 2012). Indonesia juga memiliki sumber daya alam hayati laut yang sangat potensial. Salah satunya adalah sumber daya terumbu karang yang hampir tersebar di seluruh perairan Indonesia. Luas terumbu karang Indonesia saat ini adalah $42.000 \mathrm{~km}^{2}$ atau $16,5 \%$ dari luas terumbu karang dunia, yaitu seluas $255.300 \mathrm{~km}^{2}$ (Guntur, Prasetyo \& Wawan, 2012). Dengan estimasi di atas, Indonesia menduduki peringkat terluas ke-2 di dunia setelah Australia, yang mempunyai luasan terumbu karang sebesar $48.000 \mathrm{~km}^{2}$ (Guntur, Prasetyo \& Wawan, 2012). Namun, apabila dilihat dari sisi keanekaragaman hayati, terumbu karang Indonesia merupakan pusat keanekaragaman hayati dunia dengan 70 generasi dan 450 spesies (Guntur, Prasetyo \& Wawan, 2012).

Ekosistem terumbu karang di perairan Indonesia terus mengalami penurunan, baik kuantitas, kualitas maupun estetikanya. Sebagai ekosistem yang produktif dan sangat berarti bagi penyangga sumber daya perikanan laut, ekosistem ini perlu dilestarikan. Kerusakan ekosistem terumbu karang disebabkan oleh banyak faktor, beberapa diantaranya adalah penangkapan ikan dengan cara yang merusak dengan menggunakan bom dan sianida, penambangan batu karang, sedimentasi dan faktor biologi yaitu ancaman siput Drupella.

Drupella adalah salah satu jenis invertebrata yang bersifat prasit bagi terumbu karang. Dalam kondisi yang ekstrim, invertebrata tersebut merupakan masalah yang cukup serius 
bagi keberadaan ekosistem terumbu karang. Ledakan populasi invertebrata parasit tersebut merupakan salah satu bentuk dari kondisi yang ekstrim. Jika fenomena ledakan populasi terjadi dalam waktu yang cukup lama dan dalam area yang cukup luas, ini merupakan ancaman kerusakan ekosistem terumbu karang (Riska, Sadaru, \& Haya, 2013)

Disisi lain terdapat pula beberapa jenis ikan sebagai pemangsa dari Drupella. Hubungan erat antara terumbu karang, Drupella dan Predatornya perlu dikaji keseimbangannya. Keseimbangan tersebut diperlukan untuk menjaga eksistensi terumbu karang.

\subsection{Rumusan Masalah}

Berdasarkan latar belakang yang telah diuraikan di atas maka rumusan masalah dalam penelitian ini adalah "Bagaimana Keseimbangan Interaksi Populasi Terumbu Karang, Siput Drupella dan Predatornya Melalui Phase portrait'.

\subsection{Tujuan}

Adapun tujuan yang ingin dicapai dalam penelitian ini adalah memperoleh titik kesetimbangan interaksi populasi terumbu karang, siput Drupella dan predatornya melalui phase portrait.

\subsection{Manfaat Penelitian}

Adapun Manfaat yang diharapkan dalam penelitian ini adalah sebagai berikut:

1. Mengetahui keseimbangan komposisi populasi terumbu karang, siput Drupella dan predatornya

2. Dapat dijadikan sebagai informasi mengenai populasi terumbu karang

3. Secara umum untuk mengembangkan ilmu matematika, khususnya pada bidang sistem dinamik yang diterapkan pada masalah-masalah sosial.

\subsection{Asumsi Penelitian}

Asumsi yang digunakan dalam penelitian ini adalah

1. Tidak terjadi siklus perulangan rantai makanan dalam artian prey (terumbu karang) dimangsa predator pertama (siput Drupella), predator pertama (siput Drupella) dimangsa predator kedua (ikan predator) dan tidak berlaku prey (terumbu karang) dimangsa predator kedua (ikan predator).

2. Tidak ada mangsa lain bagi siput Drupella selain terumbu karang

3. Tidak ada mangsa lain bagi predator selain siput Drupella. 


\section{METODE PENELITIAN}

Langkah-langkah yang dilakukan dalam penelitian ini yaitu

a. Memulai penelitian.

b. Melakukan tinjauan pustaka berupa terumbu karang, Drupella, Predatornya dan modell Predator-Prey tiga populasi

c. Membangun model Predator-Prey interaksi Terumbu Karang, Drupella dan Predatornya.

d. Menentukan titik-titik kritis dari model Predator-Prey interaksi Terumbu Karang, Drupella dan Predatornya.

e. Menganalisa kestabilan disekitar titik-titik kritis model Predator-Prey interaksi Terumbu Karang, Drupella dan Predatornya, dengan metode linearisasi

f. Membuat Phase portrait

g. Menyimpulkan hasil penelitian

h. Selesai.

III. HASIL DAN PEMBAHASAN

\subsection{Hasil penelitian}

3.1.1. Membangun model predator prey terumbu karang, siput Drupella dan predatornya

Penelitian ini merupakan kajian matematis dari interaksi populasi terumbu karang, siput Drupella dan predatornya. Interaksi tersebut merupakan sistem dinamik yang menyatakan hubungan antar mangsa (prey) dan pemangsa (predator) yang digambarkan dalam diagram sebagai berikut :

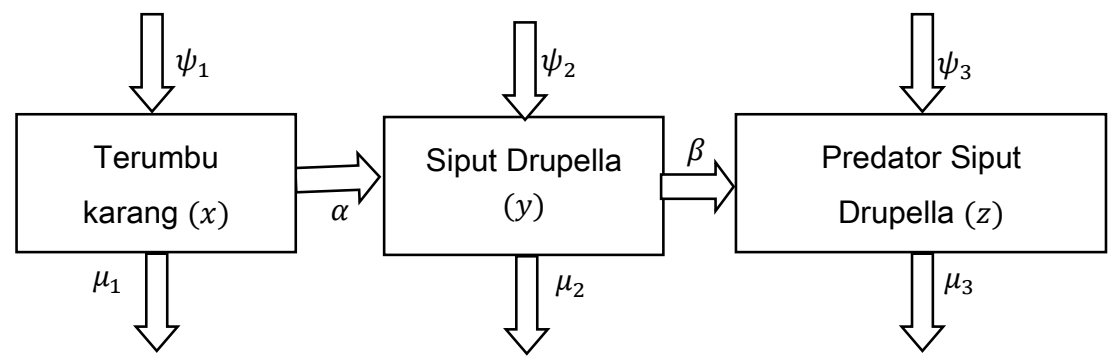

Gambar 1 : Diagram Interaksi Mangsa Pemangsa

Gambar 1 memperlihatkan bahwa siput Drupella merupakan pemangsa dari terumbu karang sekaligus menjadi mangsa bagi predatornya, sedangkan terumbu karang merupakan sumber makanan dari siput Drupella. Dari diagram tersebut 
dibangun model prey predator terumbu karang, siput Drupella dan predatornya yang diadaptasi dari model predator prey dua populasi sebagai berikut:

$\frac{d x}{d t}=x\left(\psi_{1}-\mu_{1}-\alpha y\right) ; \frac{d y}{d t}=y\left(\psi_{2}-\mu_{2}+\alpha x-\beta z\right) ; \frac{d z}{d t}=z\left(\psi_{3}-\mu_{3}+\beta y\right)$

dimana $\square, \square$ dan $\square$ secara berturut-turut adalah banyaknya populasi terumbu karang, siput Drupella dan banyaknya Predatornya.

$\psi_{\mathrm{i}} \quad$ : laju pertumbuhan alami masing-masing populasi, $\mathrm{i}=1,2,3$

$\mu_{\mathrm{i}} \quad$ : laju kematian masing-masing populasi , $\mathrm{i}=1,2,3$

$\alpha \quad$ : laju bertambahnya siput Drupella karena memangsa terumbu karang

$\beta \quad$ : laju bertambahnya Predator siput karena memangsa siput Drupella

\subsubsection{Penentuan titik kritis}

Titik kritis $\left(\mathrm{x}^{*}, \mathrm{y}^{*}, \mathrm{z}^{*}\right)$ dari sistem persamaan (1) dapat diperoleh dengan menentukan $\frac{d x}{d t}=0, \frac{d y}{d t}=0$ dan $\frac{d z}{d t}=0$, sehingga diperoleh titik-titik kritis interaksi populasi terumbu karang, siput Drupella dan predatornya dalam tabel dibawah ini.

Tabel 1 : Titik Kritis dari Interaksi Populasi terumbu karang, siput Drupella dan predatornnya

\begin{tabular}{|c|c|c|c|}
\hline Titik Kritis & $\mathrm{X}$ & $\mathrm{Y}$ & $\mathrm{Z}$ \\
\hline $\mathrm{T}_{1}$ & 0 & 0 & 0 \\
\hline $\mathrm{T}_{2}$ & 0 & $\frac{-\Psi_{3}+\mu_{3}}{\beta}$ & $\frac{\Psi_{2}-\mu_{2}}{\beta}$ \\
\hline $\mathrm{T}_{3}$ & $\frac{-\Psi_{2}+\mu_{2}}{\alpha}$ & $\frac{\Psi_{1}-\mu_{1}}{\alpha}$ & 0 \\
\hline
\end{tabular}

Titik kritis $T_{1}$ mempresentasikan kondisi tidak eksisnya semua populasi, sedangkan Titik kritis $\mathrm{T}_{2}$ menggambarkan punahnya populasi terumbu karang. Eksistensi titik kritis $T_{2}$ dipenuhi bila $\Psi_{3}<\mu_{3}$. Kondisi ini mencerminkan eksistensi siput Drupella tercapai bila terjadi penurunan populasi predator siput Drupella. Adapun syarat $\Psi_{2}>\mu_{2}$ bagi eksistensi $T_{2}$ memberi arti bahwa eksistensi predator siput Drupella terjadi apabila populasi siput Drupella bertambah. Titik kritis $T_{3}$ menggambarkan punahnya predator siput Drupella, eksistensi titik kritis $T_{3}$ dipenuhi bila $\Psi_{2}<\mu_{2}$. Kondisi ini mencerminkan eksistensi terumbu karang tercapai bila terjadi penurunan populasi siput Drupella. Adapun syarat $\psi_{1}>\mu_{1}$ bagi eksistensi $T_{3}$ memberi arti bahwa eksistensi siput Drupella terjadi apabila populasi terumbu karang bertambah.

\subsubsection{Kestabilan titik kritis}

a. Kestabilan sistem di titik kritis $T_{1}=(0,0,0)$

Hasil linearisasi di sekitar $T_{1}$ menghasilkan matriks Jacobi $J_{1}$ yaitu 
$J_{1}=\left(\begin{array}{ccc}\Psi_{1}-\mu_{1} & 0 & 0 \\ 0 & \Psi_{2}-\mu_{2} & 0 \\ 0 & 0 & \Psi_{3}-\mu_{3}\end{array}\right)$

dan diperoleh nilai eigen $\lambda_{1}=\Psi_{1}-\mu_{1}, \lambda_{2}=\Psi_{2}-\mu_{2}$ dan $\lambda_{3}=\psi_{3}-\mu_{3}$. Titik kritis ini akan stabil jika $\Psi_{1}<\mu_{1}, \Psi_{2}<\mu_{2}$ dan $\Psi_{3}<\mu_{3}$.

b. Kestabilan sistem di titik kritis $T_{2}=\left(0, \frac{-\Psi_{3}+\mu_{3}}{\beta}, \frac{\Psi_{2}-\mu_{2}}{\beta}\right)$

Titik kritis $T_{2}$ yang diperoleh bukan titik kritis $(0,0,0)$ maka akan dilakukan transformasi bidang Cartesian sehingga linearisasi sistem di titik kritis baru $T_{2}^{*}(0,0,0)$ yaitu

$J_{2}=\left(\begin{array}{ccc}\Psi_{1}-\mu_{1}+\frac{\alpha \psi_{3}-\alpha \mu_{3}}{\beta} & 0 & 0 \\ \left(\frac{-\Psi_{3} \alpha+\mu_{3} \alpha}{\beta}\right) & 0 & \Psi_{3}-\mu_{3} \\ 0 & \Psi_{2}-\mu_{2} & 0\end{array}\right)$

dan diperoleh nilai eigen $\lambda_{1}=\sqrt{\Psi_{3} \Psi_{2}-\Psi_{3} \mu_{2}-\mu_{3} \Psi_{2}+\mu_{3} \mu_{2}}, \lambda_{2}=-\sqrt{\Psi_{3} \Psi_{2}-\Psi_{3} \mu_{2}-\mu_{3} \Psi_{2}+\mu_{3} \mu_{2}}$ dan $\lambda_{3}=\Psi_{1}-\mu_{1}+\frac{\alpha \Psi_{3}-\alpha \mu_{3}}{\beta}$.

Mengingat menurut syarat eksistensi titik kritis $T_{2} \Psi_{3}-\mu_{3}<0$ dan $\Psi_{2}-\mu_{2}>0$ maka $\lambda_{1}$ dan $\lambda_{2}$ merupakan akar-akar dari bilangan negatif, akibatnya $\lambda_{1}$ dan $\lambda_{2}$ merupakan bilangan kompleks conjugate murni yang memiliki bagian real sama dengan nol. Akibatnya kestabilan sistem ditentukan dari nilai eigen $\lambda_{3}$. untuk $\lambda_{3}=\psi_{1}-\mu_{1}+\frac{\alpha \psi_{3}-\alpha \mu_{3}}{\beta}$ Menurut syarat eksistensi yaitu $\psi_{3}-\mu_{3}<0$ sehingga $\psi_{1}-\mu_{1}<0$ hasil tersebut menjadikan titik kritis $T_{2}$ stabil karena $\lambda_{3}$ bernilai negatif.

C. Kestabilan sistem di titik kritis $T_{3}=\left(\frac{-\Psi_{2}+\mu_{2}}{\alpha}, \frac{\Psi_{1}-\mu_{1}}{\alpha}, 0\right)$

Titik kritis $T_{3}$ yang diperoleh bukan titik kritis $(0,0,0)$ maka akan dilakukan transformasi bidang Cartesian sehingga linearisasi sistem di titik kritis baru $\mathrm{T}_{3}^{*}(0,0,0)$ yaitu

$J_{3}=\left(\begin{array}{ccc}0 & \Psi_{2}-\mu_{2} & 0 \\ \Psi_{1}-\mu_{1} & 0 & -\left(\frac{\beta \psi_{1}-\beta \mu_{1}}{\alpha}\right) \\ 0 & 0 & \Psi_{3}-\mu_{3}+\frac{\beta \psi_{1}-\beta \mu_{1}}{\alpha}\end{array}\right)$

dan diperoleh nilai eigen $\lambda_{1}=\sqrt{\Psi_{1} \Psi_{2}-\Psi_{1} \mu_{2}-\mu_{1} \Psi_{2}+\mu_{1} \mu_{2}}, \lambda_{2}=-\sqrt{\Psi_{1} \Psi_{2}-\Psi_{1} \mu_{2}-\mu_{1} \Psi_{2}+\mu_{1} \mu_{2}}$, 
$\lambda_{3}=\Psi_{3}-\mu_{3}+\frac{\beta \psi_{1}-\beta \mu_{1}}{\alpha}$. Titik kritis $T_{3}$ akan stabil jika kondisi berikut terpenuhi $\lambda_{1}<0$ dan $\lambda_{2}<0$ terpenuhi, dengan syarat sebagai berikut :

$$
\text { Dari } \begin{aligned}
\lambda_{1} & =\sqrt{\Psi_{1} \Psi_{2}-\Psi_{1} \mu_{2}-\mu_{1} \Psi_{2}+\mu_{1} \mu_{2}} \\
& =\sqrt{\left(\Psi_{1}-\mu_{1}\right)\left(\Psi_{2}-\mu_{2}\right)<0} \\
& =\left(\Psi_{1}-\mu_{1}\right)\left(\Psi_{2}-\mu_{2}\right)>0
\end{aligned}
$$

Mengingat menurut syarat eksistensi titik kritis $T_{3} \quad \Psi_{2}<\mu_{2}$ dan $\psi_{1}>\mu_{1}$ maka $\lambda_{1}$ dan $\lambda_{2}$ merupakan akar-akar dari bilangan negatif, akibatnya $\lambda_{1}$ dan $\lambda_{2}$ merupakan bilangan kompleks conjugate murni yang memiliki bagian real sama dengan nol. Akibatnya kestabilan sistem ditentukan dari nilai eigen $\lambda_{3}$. Dari $\lambda_{3}=\Psi_{3}-\mu_{3}+\frac{\beta \psi_{1}-\beta \mu_{1}}{\alpha}$, menurut syarat eksistensi $\square_{1}>\square_{1}$ maka $\square_{3}>\square_{3}$ sehingga $\square_{3}$ dijamin bernilai positif jadi titik kritis $\square_{3}$ tidak stabil.

3.1.4. Phase portrait model interaksi populasi terumbu karang, siput Drupella dan predatornya

Adapun phase portrait model interaksi populasi terumbu karang, siput Drupella dan predatornya dapat digambarkan sebagai berikut :

a. Phase portrait di sekitar titik kritis $\mathrm{T}_{1}=(0,0,0)$

Untuk nilai-nilai $\Psi_{1}, \Psi_{2}, \Psi_{3}, \mu_{1}, \mu_{2}, \mu_{3}$, a dan $\beta$ sedemikian tidak dipenuhi syarat kestabilan maka nilai-nilai parameternya yaitu $\Psi_{1}=0,8, \Psi_{2}=0,9, \quad \Psi_{3}=0,7, \mu_{1}=0,6$, $\mu_{2}=0,25, \mu_{3}=0,5, \alpha=0,9$ dan $\beta=0,1$ diperoleh nilai eigennya yaitu $\lambda_{1}=0,2, \lambda_{2}=0,65$ dan $\lambda_{3}=0,2$ Sehingga titik kritis $T_{1}(0,0,0)$ bersifat tidak stabil. Hal tersebut dapat dilihat melalui gambar phase portrait 2 dengan nilai awal $x(0)=0.01, y(0)=0.01$ dan $z(0)=0.01$.

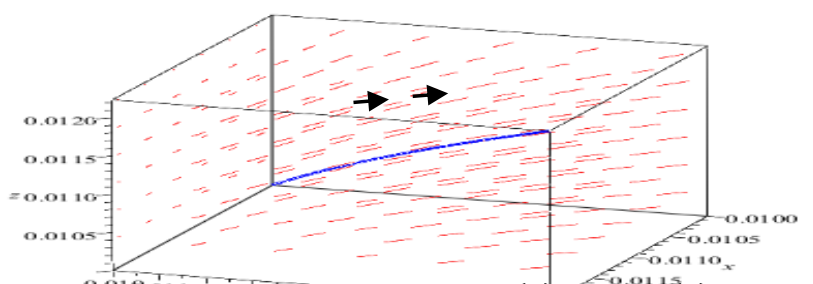

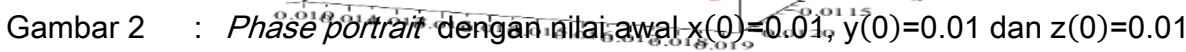

Kestabilan sistem titik kritis $T_{1}$ dengan $\lambda_{1}>0, \lambda_{2}>0$ dan $\lambda_{3}>0$ adalah Tidak Stabil dengan tipe Saddle node. Dalam hal memenuhi syarat kestabilan $\square_{1}$ maka nilai-nilai parameternya yaitu $\Psi_{1}=0,6, \Psi_{2}=0,25, \Psi_{3}=0,5, \mu_{1}=0,8, \mu_{2}=0,9, \mu_{3}=1,9, \alpha=0,9$ dan $\beta=0,1$ diperoleh nilai eigen sistem yaitu $\lambda_{1}=-0,2, \lambda_{2}=-0,65$ dan $\lambda_{3}=-0,2$. Sehingga titik kritis 
$\mathrm{T}_{1}(0,0,0)$ bersifat stabil. Hal tersebut dapat dilihat melalui gambar phase portrait 3 dengan nilai awal $x(0)=0.01, y(0)=0.01$ dan $z(0)=0.01$.

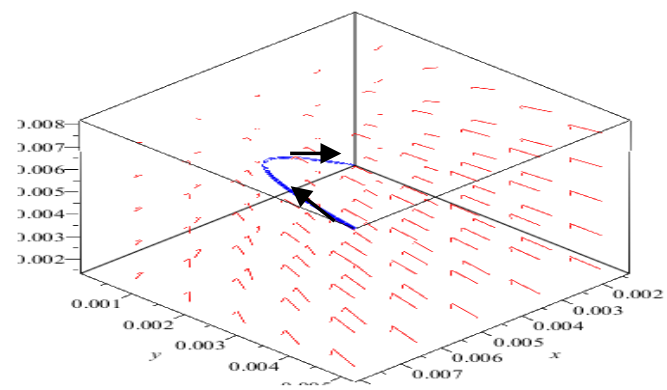

Gambar 3 : Phase portrait dengan nilai awal $x(0)=0.01, y(0)=0.01$ dan $z(0)=0.01$.

b. Phase portrait di sekitar titik kritis $\mathrm{T}_{2}=\left(0, \frac{-\psi_{3}+\mu_{3}}{\beta}, \frac{\Psi_{2}-\mu_{2}}{\beta}\right)$

Untuk nilai-nilai parameter $\Psi_{1}=0,6, \Psi_{2}=0,9, \quad \Psi_{3}=0,5, \mu_{1}=0,8, \quad \mu_{2}=0,25$, $\mu_{3}=0,7, \alpha=0,9 \quad$ dan $\beta=0,1$ diperoleh nilai eigen sistem adalah $\lambda_{1}=0,36 i$, $\lambda_{2}=-0,36 i$ dan $\lambda_{3}=-2$. Sehingga titik kritis $T_{2}(0,2,6,5)$ bersifat stabil.

Hal tersebut dapat dilihat melalui gambar phase portrait 4 dengan nilai awal $x(0)=0,01, y(0)=1, z(0)=3$ di bawah ini

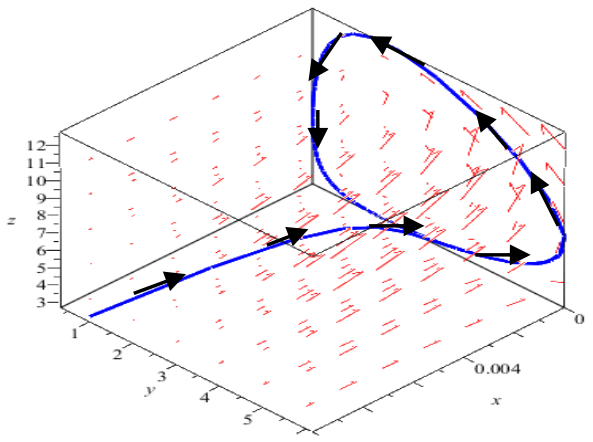

Gambar 4 : Phase portrait dengan nilai awal $x(0)=0.01, y(0)=1$ dan $z(0)=3$

Kestabilan sistem titik kritis $T_{2}$ dengan $\lambda_{1.2} \pm \mu$ i dan $\lambda_{3}<0$ adalah Stabil dengan tipe spiral.

C. Phase portrait di sekitar titik kritis $\mathrm{T}_{3}=\left(\frac{-\Psi_{2}+\mu_{2}}{\alpha}, \frac{\Psi_{1}-\mu_{1}}{\alpha}, 0\right)$

Untuk nilai-nilai parameter $\Psi_{1}=0,8, \quad \Psi_{2}=0,25, \quad \Psi_{3}=0,7, \mu_{1}=0,6, \mu_{2}=0,9$, $\mu_{3}=0,5, \alpha=0,9$ dan $\beta=0,1$ diperoleh nilai eigen sistem adalah $\lambda_{1}=0,36 i, \lambda_{2}=-0,36 i$ dan $\lambda_{3}=0,22$ Sehingga titik kritis $T_{3}(0,72,0,22,0)$ bersifat tidak stabil. 
Hal tersebut dapat dilihat melalui gambar phase portrait 5 dengan nilai awal $x(0)=1, y(0)=1$ dan $z(0)=0,01$.

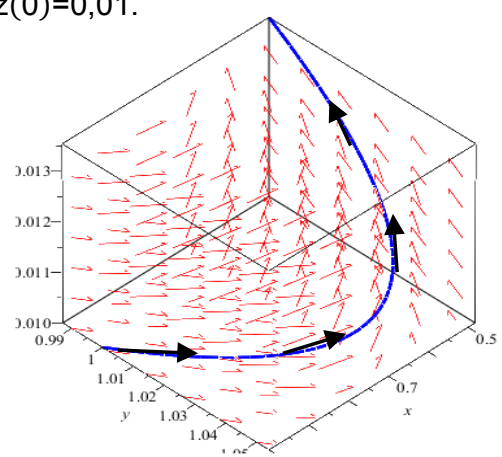

Gambar 5 : Phase Portrait dengan nilai awal $x(0)=1, y(0)=1$ dan $z(0)=0,01$

Kestabilan sistem titik kritis $T_{3}$ dengan $\lambda_{1.2} \pm \mu$ idan $\lambda_{3}>0$ adalah Tidak Stabil dengan tipe Saddle node.

\subsection{Pembahasan}

Sistem dinamik persamaan diferensial (1) memberikan titik kritis $T_{1}=(0,0,0)$, $\mathrm{T}_{2}=\left(0, \frac{-\Psi_{3}+\mu_{3}}{\beta}, \frac{\Psi_{2}-\mu_{2}}{\beta}\right)$ dan $\mathrm{T}_{3}=\left(\frac{-\Psi_{2}+\mu_{2}}{\alpha}, \frac{\Psi_{1}-\mu_{1}}{\alpha}, 0\right)$. Titik kritis $\mathrm{T}_{1}=(0,0,0)$ merepresentasikan kondisi tidak eksisnya semua populasi. Sedangkan titik kritis $T_{2}=\left(0, \frac{-\psi_{3}+\mu_{3}}{\beta}, \frac{\Psi_{2}-\mu_{2}}{\beta}\right)$ menggambarkan punahnya populasi terumbu karang. Eksistensi titik kritis $T_{2}$ dipenuhi bila $\Psi_{3}<\mu_{3}$. Kondisi ini mencerminkan eksistensi siput Drupella tercapai bila terjadi penurunan populasi siput Drupella, adapun syarat $\psi_{2}>\mu_{2}$ bagi eksistensi $T_{2}$ memberi arti bahwa eksistensi predator siput Drupella bertambah. Titik kritis $T_{3}=\left(\frac{-\Psi_{2}+\mu_{2}}{a}, \frac{\Psi_{1}-\mu_{1}}{a}, 0\right)$ menggambarkan punahnya predator siput Drupella, eksistensi titik kritis $T_{3}$ dipenuhi bila $\Psi_{2}<\mu_{2}$. Kondisi ini mencerminkan eksistensi terumbu karang tercapai bila terjadi penurunan populasi siput Drupella. Adapun syarat $\psi_{1}>\mu_{1}$ bagi eksistensi $T_{3}$ memberi arti bahwa eksistensi siput Drupella terjadi apabila populasi terumbu karang bertambah.

Berdasarkan nilai parameter yang digunakan pada gambar 2 phase portrait menyebabkan sistem di titik kritis $\mathrm{T}_{1}=(0,0,0)$ tidak stabil dengan tipe Saddle node. Sedangkan pada gambar 3 phase portrait menyebabkan sistem di titik kritis $T_{1}=(0,0,0)$ stabil dengan tipe Spiral. Phase portrait solusi pada gambar 4 sistem di titik kritis $\mathrm{T}_{2}=\left(0, \frac{-\Psi_{3}+\mu_{3}}{\beta}, \frac{\Psi_{2}-\mu_{2}}{\beta}\right)$ Stabil dengan tipe Spiral. Berdasarkan nilai parameter yang digunakan 
pada gambar 4.6 phase portrait menyebabkan sistem di titik kritis $T_{3}=\left(\frac{-\psi_{2}+\mu_{2}}{\alpha}, \frac{\psi_{1}-\mu_{1}}{\alpha}, 0\right)$ tidak stabil dengan tipe Saddle node.

Pada saat sistem memiliki satu titik kritis yang stabil $T_{2}$ dan dua titik kritis tidak stabil $T_{1}$ dan $T_{3}$, lintasan maju dari titik-titik kritis dapat digambarkan sebagai berikut :

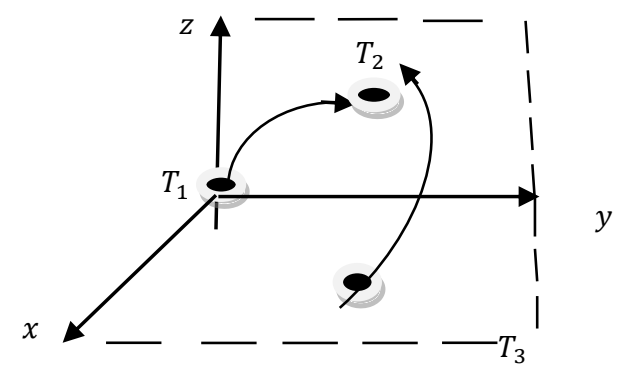

Gambar 6 : Lintasan maju satu titik kritis stabil dan dua titik kritis tidak stabil

Selain itu, pada saat sistem memiliki dua titik stabil $T_{1}, T_{2}$ dan satu titik kritis tidak stabil $T_{3}$ maka akan terjadi perubahan lintasan sebagai berikut :

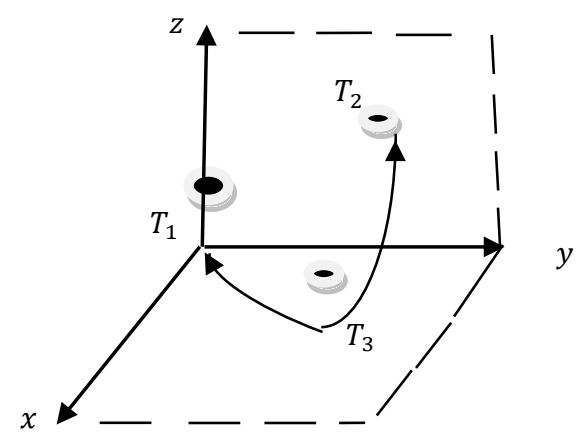

Gambar $7 \quad$ : Lintasan maju dua titik kritis stabil dan satu titik kritis tidak stabil

Dengan demikian terdapat perubahan perilaku sistem yang diakibatkan oleh perubahan nilai parameter. Perubahan perilaku sistem akibat perubahan nilai parameternya disebut bifurkasi, dalam penelitian ini jenis bifurkasi yang muncul adalah bifurkasi pitchfork.

\section{KESIMPULAN}

Berdasarkan hasil penelitian yang telah dilakukan, maka dapat disimpulkan sebagai berikut:

1. Model Keseimbangan Interaksi Populasi Terumbu Karang , Siput Drupella dan Predatornya dinyatakan dalam sistem diferensial sebagai berikut :

$\frac{\mathrm{dx}}{\mathrm{dt}}=\mathrm{x}\left(\Psi_{1}-\mu_{1}-\mathrm{ay}\right)$ 


$$
\begin{aligned}
& \frac{d y}{d t}=y\left(\Psi_{2}-\mu_{2}+\alpha x-\beta z\right) \\
& \frac{d z}{d t}=z\left(\Psi_{3}-\mu_{3}+\beta y\right)
\end{aligned}
$$

Model memiliki tiga titik kritis yaitu $T_{1}=(0,0,0), T_{2}=\left(0, \frac{-\Psi_{3}+\mu_{3}}{\beta}, \frac{\Psi_{2}-\mu_{2}}{\beta}\right)$ dan $T_{3}=\left(\frac{-\Psi_{2}+\mu_{2}}{\alpha}, \frac{\Psi_{1}-\mu_{1}}{\alpha}, 0\right)$.

2. Phase portrait model keseimbangan Interaksi Populasi Terumbu Karang, Siput Drupella dan Predatornya pada titik kritis $\mathrm{T}_{1}=(0,0,0)$ menunjukan bahwa sistem akan stabil jika memenuhisyarat kestabilan yaitu $\Psi_{1}<\mu_{1}, \Psi_{2}<\mu_{2}$ dan $\Psi_{3}<\mu_{3}$.

3. Phase portrait model keseimbangan Interaksi Populasi Terumbu Karang, Siput Drupella dan Predatornya pada titik kritis $\mathrm{T}_{2}=(0,2,6,5)$ menunjukan bahwa sistem stabil dengan tipe spiral.

4. Phase portrait model keseimbangan Interaksi Populasi Terumbu Karang, Siput Drupella dan Predatornya pada titik kritis $T_{3}(0,72,0,22,0)$ menunjukan bahwa sistem tidak stabil.

5. Sistem memiliki dua titik kritis stabil dan satu titik kritis tidak stabil yang berubah menjadi satu titik kritis stabil dan dua titik kritis tidak stabil. Perubahan tersebut disebabkan karena perubahan parameter yang disebut sebagai bifurkasi. Jenis bifurkasi yang ditemukan adalah pitchfork.

6. Interaksi populasi yang mempertimbangkan eksistensi populasi terumbu karang pada titik kritis $T_{3}$ yang tidak stabil akan bergerak menuju titik kesetimbangan $T_{2}$. Hal ini menunjukkan perlunya upaya khusus untuk menjaga eksistensi populasi terumbu karang.

\section{DAFTAR PUSTAKA}

[1]. Anonim. Ikan-ikan Predator. (http://sdi.kkp.go.id/index.php/arsip/c/797/cara-makan-danhubungan-sifat-morfologi-dengan-kebiasaan-makanan-/?category_id=27). Diakses 18 Maret 2014.

[2]. Anton, H. 1987. Dasar-dasar aljabar linear, Jilid 2. Binarupa Aksara. Ciputat - Tanggerang.

[3]. Guntur, Prasetyo, D. \& Wawan. 2012. Pemetaan Terumbu Karang Teori, Metode, dan Praktik. Ghalia Indonesia, Hal 3-4 \& 9-10. Bogor.

[4]. P, O. 2012. Siput Drupella. (http://dzuloceano.blogspot.com/2012/11/Drupella-sppzoologi.html?m=1). Diakses 18 Maret 2014.

[5]. P S, R. 2009. Diktat Kuliah MA2271 Metoda Matematika Semester // 2010/2011. (http://personal.fmipa.itb.ac.id/sr_pudjap/files/2009/08/DiktatMA2271.pdf). Diakses 09 Februari 2015. 
[6]. Anonim. Rehabilitasi terumbu karang dengan transpalantasi. (http://kamiahlinya.blogspot.com/2010/09/rehabilitasi-terumbu-karang-dengan .html)., Diakses 11 April 2014

[7]. Riska, Sadaru, B. \& Haya, L. O. 2013. Kelimpahan Drupella Pada Perairan Terumbu Karang di Pulau Belan-Belan Besar Selat Tiworo Kabupaten Muna, Sulawesi Tenggara. Mina Laut Indonesia , 69-80.

[8]. Rozi, S. 2006. Bifurkasi dari persamaan diferensial dan sistem persamaan diferensial dimensi dua.http://www.google.co.id/url?sa=t\&rct=j\&q=\&esrc=s\&source=web\&cd=1 ved=0CEQF jAA\&url=http\%3A\%2F\%2Flib.ui.ac.id\%2Ffile\%3Ffile\%3Ddigital\%2F20180878-S27618 Syamsyida\%2520Rozi.pdf\&ei=sPoMVM_2Ao6MuASZ6oDoBQ\&usg=A QjCNE1q8tovbOr-CEkpnRjKVvwsQT_Vg\&bvm=bv.74649129,d.c2E). Diakses 04 September 2014.

[9]. Tu, P. N. V. 1994. Dynamical system An Introduction with application in economics and biologi, Springer-Verlay. Germany. 